\title{
Public Expectations in Local Governance: Unit Committees under Ghana's Decentralised System
}

\author{
Gabriel Botchwey \\ University of Education, Winneba, Ghana \\ gkabotchwey@uew.edu.gh \\ DOI//http://dx.doi.org/10.4314/gjds.v14i1.9
}

\begin{abstract}
Effective democratic governance requires the existence of locally elected representatives with functions that revolve around issues that matter to the constituents, to which the state responds through public services delivery. This study set out to examine whether or not citizen expectations from locally elected representatives are in consonance with the functions that are assigned to them in national legislative instruments, using the Unit Committees, the base structure of Ghana's decentralised system as a case for close examination. The study was conducted through qualitative semi-structured interviews, covering four districts in the central region of Ghana. Findings show that there are several points of dissonance or asymmetry regarding what local citizens expect from their representatives, the functions assigned by the national statutes, and what the local representatives have actually being doing at the local level. Fundamentally, local citizens expect their elected representatives to be involved in addressing pertinent public services delivery deficits, but statutory provisions allocate functions that many Unit Committees are not even aware of, or cannot simply perform in their current state. These disparities, coupled with lack of training, funding and disregard for the role of local representatives account for their largely comatose existence under Ghana's decentralised system. To remedy this situation, greater space is required in the crafting of legislation to allow local realities to take centre stage in the functions assigned to locally elected representatives in local governance, and to establish a sustainable funding system to support their role.
\end{abstract}

Keywords: Governance, Decentralisation, Public Services Delivery, Unit Committees, Ghana

\section{Introduction}

In general, decentralisation programmes were introduced in several countries, both developed and developing, with very positive developmental and democratic expectations (UNDP, 2002:7-14). These include granting powers and resources necessary to carry out local governance tasks effectively; bringing decision making closer to the people, and making government better able to deliver programmes and services that address local needs; creating more opportunities for citizens to participate at 
civil society level; and building the capacity of local actors to play leading roles in the development and management of their area and communities (Work, 2002:3-4; UNDP, 2002:7-14). With government brought closer to citizens, decentralisation is expected to provide informational advantage to enable local authorities ensure better equity in the distribution of resources, provide services that respond to local needs, and attain efficiency in service delivery (Brinkerhoff \& Azfar 2006:21; Smoke, 2003:9).

However, preliminary outcomes of decentralisation programmes in many countries indicate asymmetries between theoretical intentions of implementing state authorities on one hand, and citizen expectations on the other. Whiles discrepancies between theoretical expectations and implementation realities at the national level have been widely researched (see Botchwey 2014; 2011; Crawford 2009; Steiner 2007; Ayee 2005; Olowu and Wunsch 2004; Ribot 2002), this study focuses on expectations of citizens from locally-elected representatives, and statutory functions and roles assigned to locally-elected representatives under decentralised governance. This paper examines why asymmetric expectations and hostility arise between citizens and locally-elected representatives under local governance.

The key questions that this study sought to examine include the following: what are the issues that matter to local citizens, and what do they expect their locally-elected leaders to do about them? How do these interface with national statutory expectations or roles assigned to the representatives? What do the findings reveal about policy making and practice in local governance? These questions are examined with a focus on Ghana's Unit Committees (UCs), which constitute the basic structure of the local government system. The UCs in Ghana have been selected for close investigation because there appears to be a disillusion with local representatives in many communities in Ghana, leading some citizens to hurl insults at the UC members and physically assaulting some. Previous research has also indicated instances of power struggles between Chiefs and UCs, and between Assembly members and UCs to the extent that they it becomes extremely difficult for the parties to work together (Botchwey, 2011). It has also been observed that UCs receive little recognition and motivation for their work from both the state and the electorate (USAID 2003:8, in: Crawford 2004). However, the UCs within the local government system play crucial positive roles in some communities such as organising communal labour, helping with extension of electricity and water, managing garbage collection and others. This study therefore set out to investigate what local citizens expect from their locally elected representatives; how these interface with national statutory expectations of locally elected representatives; and what accounts for the rise of asymmetric expectations and hostility between citizens and elected representatives at the local level? 


\section{Decentralisation and Local Governance: Theoretical Perspective}

Decentralisation involves the process of transferring power and resources from central government to lower levels of government such as regions, provinces, districts and municipalities (Work, 2002:5: Manor, 1995:5); it is closely linked to the principle of subsidiarity which proposes that functions that could be performed at lower levels in a hierarchy should not be taken up at higher levels but devolved to the lower levels that are capable of completing them (Work, 2002:5). The term decentralisation emerged in the 1950 s and 1960s when the British and French colonial administrations devolved responsibilities for certain functions and activities to local authorities as part of their rule. However, decentralisation moved to the forefront of the development agenda in the 1980s and 1990s as an integral part of the search for good governance (World Development Report 1999/200o). Decentralisation has received support from traditional political ideology opponents due to its prospects and this has been aptly expressed by Bardhan (2002) as follows:

Its [decentralisation] potential benefits have attracted a very diverse range of supporters, from free-market economists at one extreme edge of the ideological spectrum, who stress the benefits of reducing the power of the overextended State, to «anarcho-communitarians» on the other, who are both anti-market and anti-centralized State and strongly support assignment of control to local self-governing communities (Bardhan, 2002, in Jette, 2005:7).

Decentralisation programmes have been conceptualised and implemented in different ways, and Manor (1995:5) has discussed three of these, namely: devolution (democratic decentralisation), deconcentration (administrative decentralisation) and fiscal decentralisation. Devolution or democratic decentralisation involves the transfer of power and resources to sub-national authorities that are relatively independent of central government and have been democratically elected. This represents the ideal type of decentralisation that grants maximum political autonomy and administrative discretion to local authorities and enables them to make independent choices according to local circumstances. Deconcentration or administrative decentralisation refers to the transfer of authority to sub-national offices of the central State including government institutions such as officials of ministries and departments represented at the local level; however, they remain directly accountable to national headquarters and not to the local authority or administration. This often leads to situations where local populations have very little control over the activities of the departments or the officials since they do not report to them (Ayee, 2005; Crawford, 2009). Fiscal decentralisation involves the transfer of authority over budgets to deconcentrated officials, unelected appointees, or elected politicians and local authorities by central government (Manor, 1995:5). However, 
it is important to note that fiscal decentralisation is not accepted by all scholars as a distinct type of decentralisation since fiscal transfers are involved in all other types of decentralisation; thus it has come to be seen by some authors as a crosscutting issue in the decentralisation discourse (Ribot, 2002:iii).

Decentralisation as understood and used in this paper refers to democratic decentralisation, which Ribot (2002:4) defined as follows:

Political or democratic decentralization occurs when powers and resources are transferred to authorities representative of and downwardly accountable to local populations. Democratic decentralization aims to increase popular participation in local decision making. Democratic decentralization is an institutionalized form of the participatory approach. This is considered the "strong" form of decentralization-the form that theoretically provides the greatest benefits.

There have also been contestations regarding whether decentralisation discussions should be restricted to the vertical process of shifting power from central government level to lower levels alone or whether it should include horizontal dimensions which involve the shifting of competencies and resources at a given level through delegation and privatisation (Rondinelli and Cheema, 1983:21-25). Countries that have implemented decentralisation programmes have incorporated aspects of both vertical and horizontal dimensions of decentralisation in response to their objectives and circumstances.

\section{Decentralisation and Public Services Delivery}

The delivery of satisfactory public services for citizens by government has been one of the key motivations for community empowerment and community driven development and it has been a rallying point that spurs collective action to engage public authorities (Narayan, 2002; Binswanger and Aiyar, 2003; World Bank, 2004; Brinkerhoff and Azfar, 2006). Citizens' demand for better services from public institutions has continued to be part of community development activities and this has led to the need for communities and voluntary sector actors to build capacity to work in partnership with local governments to deliver services. In community development, services that members of the community consider as priority tend to serve as the rallying points for collective action. Decentralisation is also expected to lead to improved delivery of public services for people in local communities. Three key areas through which this could be achieved include better matching of public services to citizens' needs and preferences, improved technical efficiency resulting from a race to the top among different competing 
local governments and service providers, and increased innovations through the development of local solutions to problems (Brinkerhoff \& Azfar, 2006:5).

Even though decentralisation promises to provide better informational advantage to officials to respond appropriately to the needs of local citizens, studies by Azfar et al. (2001) in Uganda, the Philippines and other developing countries have reported that public officials showed either very weak or no evidence of having acquired better knowledge of the preferences of local inhabitants, after implementation of decentralisation (Brinkerhoff \& Azfar, 2006:21). This was supported by Manor (2006) who noted that there appears to be only imperfect transmission of knowledge about local preferences. Thus, informational advantage which leads to better matching of services to citizen preferences does not seem to be occurring, especially in developing country situations.

\section{Decentralisation in Ghana}

Decentralisation was first introduced in the Gold Coast by the British colonial administration which formally declared the Gold Coast a colony and governed it from 1850 to 1957 (Larbi et al, 2003:117). Decentralisation was introduced as part of indirect rule in the 1930s through the chiefs and elders of towns and villages, principally because it was more challenging to maintain control over local populations and resources directly (Ayee 2000; Wardell \& Lund, 2006:1887). Chiefs wielded considerable authority over their people, who in turn held strong allegiance to the chiefs. Ostensibly, concerns about possible competition with the chiefs for the allegiance of the people also contributed to the choice of indirect rule which effectively changed the role of the chiefs from competitors to collaborators in the British colonial administration. Chiefs were therefore legally empowered by the colonial administration to establish treasuries, appoint staff and perform local government functions (Nkrumah, 2000:55). Thus, the motive for indirect rule introduced from 1878 to 1951 was not necessarily to give voice and power to the local population but seems to be a strategy to avoid political competition and to maintain control. The involvement of chiefs in the colonial administration consequently affected relationships with their people because they came to be regarded as part of the colonisers, and this seems to have contributed to the resentment and resistance against their involvement in active politics even after independence. To date, the present constitution (1992) states that: 'A person shall not be eligible to be a Member of Parliament if he... is a chief (Article 94, 3, c). Article 276 (1) of the same constitution specifically states that: 'A chief shall not take active part in party

politics; and any chief wishing to do so and seeking election to Parliament shall abdicate his stool or skin.' These constitutional provisions effectively removed key traditional political leaders and organisers of local communities from national political life. 
More than 50 years after independence, the exclusion of chiefs continues to prevail even though they may be appointed by the President to public positions for which they are qualified such as serving on governing boards and councils. This exemplifies a situation of replacing the rights of chiefs to participate in governance with a discretionary power which is now the prerogative of the executive. At the local government level, chiefs (also referred to as traditional authorities) are conspicuously missing from the list of functionaries and power brokers in the District, but the President, again, may consult them in appointing 30 per cent of the Assembly Members (ILGS, 2008:17; Local Government Act 462, 5, d). Many chiefs and the public remain dissatisfied with the situation and have been lobbying governments for changes in the laws; and it was in response to these that the National House of Chiefs and the Ministry of Chieftaincy Affairs were established in Ghana. The Ministry was established in accordance with the Civil Service Law, 1993 (PNDC Law 327). Its establishment was facilitated through the recommendation of the African Peer Review Mechanism (APRM) and in response to persistent Ghanaian public opinion. These have served as a voice for chiefs and granted them some visibility in national affairs.

\section{The Structure of Ghana's Current Decentralised System (1992-to date)}

The 1992 constitution provided the strongest legal backing to the present decentralisation and local government system in Ghana. The system has five local government levels with the Regional Coordinating Councils at the top, followed by Municipal/Metropolitan/District Assemblies, Sub-Metropolitan Districts, Urban/Town/ Area/Zonal Councils, and Unit Committees at the base.

By way of clarification, the demarcations between a Metropolitan, Municipal and District Assembly are based on population size. A Metropolitan Assembly is a local government unit with a population above 250,000 persons; a Municipal Assembly with a population above 95,000 persons and one town Assembly; and a District Assembly with a population between 75,000-95,000 persons. Ghana currently has 6 Metropolitan Assemblies, 40 Municipal Assemblies and 170 District Assemblies, making a total of 216 local government administrations (Ghana Districts, 2016). For the purpose of this study, the term District Assembly is used to refer to all the local government administrations without any prejudice. It is also important to note that District Assemblies remain the key interface between central government and people at the district level, with the Regional Coordinating Council playing a supervisory role.

\section{Locally-elected Representatives}

With reference to this study, the relevant elected representatives at the local level in Ghana's decentralisation system include the Members of Parliament (MPs), Assembly 
Members and the Unit Committees (UCs), the primary focus of this study. The functions of the MP include identifying problems of the electorates so as to advocate for their needs in Parliament, among others (ILGS, 2008:19), all of which are spelt out in their respective legislative instruments and standing orders. The Assembly Member's duties include providing adequate information about their particular community to the District Assembly (DA), lobbying the DA on behalf of their communities and to assist in monitoring and evaluation of programmes and projects in their communities (ILGS, 2008:19-20). A Unit normally refers to a settlement or group of settlements with a population size between 500-1,000 people in rural areas, but the population may be higher in urban areas (NCCE 1998:3). A Unit Committee consists of not more than five persons publicly elected at an election conducted by the Electoral Commission of Ghana, and its members hold office for four years and are eligible for re-election (Legislative Instrument 1967, sections 23 and 24). It is estimated that there are some 5,000 Unit Committees (UCs) spread over the country; however, many of them suffer legitimacy problems from members of the community and traditional authorities. Some community members often regard them as appendages to the government in power, whilst some traditional leaders also compete with them for control over decisions, activities, and for attention from government and citizens. It is also significant to note that UCs do not receive remuneration or any meaningful recognition for their role and the work they do in their communities. It remains, by many standards, a sacrificial duty unless members who have political aspirations decide to use it as a springboard to national politics (USAID 2003:8, in Crawford 2004).

\section{Methodology}

The study was carried out through qualitative semi-structured interviews, with a purposive sample from four local government (LG) administrations selected on the basis of the issues or research questions of the study, and to ensure that it captures relevant views and experiences from participants in older and newly-created local government (LG) administrations or units. To this end, two older LG units established in 1987/1988 when the present local government system was introduced were selected; and two newly-created LG units (2009/2010) were also selected for participation in the study. By this process, four local government units that qualified to participate were Gomoa West District Assembly, Agona West Municipal Assembly, Gomoa East District Assembly and Agona East District Assembly.

Ninety four (94) interviews were conducted from January to July 2014, with some follow ups and document analysis in 2015 and 2016. The respondents included past and present Unit Committee members and Assembly members, local government officials, chiefs and elders, opinion leaders and ordinary residents in urban and rural communities 
involving women, men, and the youth. Data was collected mainly through face-toface interviews and self-completion of interview guides. The questions posed during interviews bordered on problems that communities face in their daily activities or on regular basis; public services delivery; involvement of UCs in public services delivery; general activities of UCs; and what respondents expect the UCs to be doing, and others. The data collection team was given some training in interviewing and recording skills before the exercise and this facilitated the research process, and the follow ups that were undertaken after the first round of data collection. Document review and analysis were also undertaken to cross-check and triangulate the data collected to ensure its quality and accuracy. A largely thematic approach was adopted for analysis of the data collected, and this focused on areas of convergence, divergence and the explanations that account for these. This was followed by an analysis of their implications in terms of policy and practice in decentralised governance, regarding what citizens expect from locallyelected representatives. The subsequent sections discuss the findings of the study.

\section{Findings}

\section{Problems Regularly Encountered by Communities}

Findings from the study revealed a range of problems that communities regularly face, and many of these were related to public services delivery. The services in contention include water, electricity, waste collection, education and healthcare; others mentioned in interviews include security, births and deaths registration. Incidentally, most of these happen to be the issues that community residents expect their locally elected representatives to address or at least to help manage. These are later examined in view of Legislative Instrument 1967, Fourth Schedule (2010), in terms of what it expects the UC members to be doing.

Regarding water supply, many respondents complained about poor water supply with incommensurate high tariffs. Some communities did not have any pipe-bone water at all and had to rely on streams or boreholes, some of which did not produce drinkable water, or were not working. In other cases, the pipelines only existed in some sections of the community, leaving out new built up areas that were developing. Similar concerns were expressed about electricity supply. In some communities, there was no electricity; in other cases, new built up areas were left without power, and the residents have to buy their own electricity poles, pay for cables and contractors to extend electricity from the national grid to their homes. Meanwhile, as soon as power has been extended to the homes, the poles and cables legally become the property of the national electricity company after 24 hours, as indicated on the electricity company's forms. This has left most people in new built up areas very dissatisfied. In addition, there were reports of 
frequent power cuts without any prior information or explanation. In other cases, the electricity current or output was so low that it could not be used for any meaningful economic activity.

Collection of waste was also mentioned as a major problem by many respondents in all the four districts studied. In some communities, there were no bins or large collection containers for residents to use, and so waste is dumped indiscriminately. In others, there were large collection containers but when the containers get full, they were left uncollected for a long period of time and begins to pose serious health problems for residents due to the stench, flies, germs and bacteria generated from the decomposing waste (interview with community members, Gomoa East, 25 and 27 January 2014). This often occurs for weeks and months before the containers are removed and emptied. This was a major problem in urban areas where collection of garbage containers is very irregular. Another consequence is that, some residents dump their waste anywhere they can find. Some also dump their refuse indiscriminately even where there are refuse containers due to unwillingness to pay the levy for use of the containers, absence of appropriate sanctions to deter such behaviour, or a lack of enforcement where they exist. Another related issue to waste management concerns lack of adequate toilet facilities, leading to indiscriminate defecation and frequent health problems such as cholera and others in many communities.

Concerning education, there were complaints about teachers not coming to school regularly or on time. The poor performance of pupils, especially from public schools, in the Basic Education Certificate Examination (BECE) was mentioned several times as a matter of deep concern. It also emerged that many children were no longer interested in schooling or apprenticeship but were looking for avenues to make quick money; others were being used by parents in the farms, markets or in business activities during school hours. Many communities also lacked libraries to support academic activities, and indeed, in one of the districts studied, there was no public library in the entire district. Regarding healthcare, some communities lacked health centres and therefore faced difficulties with seeking treatment for illnesses at night, especially for children. When people fall sick at night in communities without a clinic or health centre, the consequences become fatal due to lack of ambulances or vehicles to cater for emergency cases. It was also reported that some health care workers were very rude to users of the service, and should therefore be retrained or replaced (interview with former UC member, Agona East, 19 March 2014).

Poor security was also raised as a major concern. In many communities, there were no police personnel to provide security, leading to repeated robberies. To make matters worse, there were no street lights, providing a suitable cover for robberies to take place indiscriminately (interview with UC member, Gomoa East, 16 January 2014). In some 
instances, the police were accused of failing to make arrests when complaints were lodged against criminal activities and for breaches of the law. In other cases, drug users and 'wee' smokers harass community residents through theft and physical assaults, and the police were accused of turning a blind eye to these. Concerning births and deaths, it emerged that most people were not aware of the need to register these, or where to do it; this was particularly worse with registration of deaths. Only few deaths were registered, usually where the deceased was a formal employee with potential social security benefits or insurance entitlements that could be claimed by the surviving family. Apart from these, most people do not bother to register deaths (interview with Assembly member, Agona East, 6 March 2014).

Another major problem at the local level was political polarization where many chiefs, Assembly members and the UC members were not united, and therefore unable to work together because of political differences. For example, a chief may belong to political party A and the Assembly member belongs to political party B, and they therefore regard each other as competitors rather than collaborators (interview with community member, Gomoa East, 21 January 2014). In other instances, Unit Committee members belonged to opposing political parties, and were therefore unable to work together among themselves, or to work with an Assembly member or chief who belonged to different political parties. In some communities, this has stifled any spirit of cooperation to the extent that common cultural and traditional events and festivals have been negatively affected (interview with Assembly member, Gomoa East, 8 January 2014). Some community residents also refuse to participate in communal labour because they feel it is the job of the politicians or the supporters of the political party in power. There were also allegations of public officials giving out contracts, and failing to monitor them to ensure quality or timely delivery, with regard to construction of school buildings, bridges and culverts, gutters and others. Other problems mentioned include lack of community markets to promote trading and economic activities.

\section{What Community Residents Expect from Unit Committees (UCs)}

Evidence from the study indicated that community residents expect a number of things from their UCs. These include supporting public services delivery, civic education, better cooperation between Assembly members and the UCs, among the UCs themselves, and more effective engagement between the residents and the UCs. In addition, they expect UCs to be more involved in engagements between the local government and the community; to be involved in project monitoring and execution where feasible; to organise communal labour; to be involved in revenue mobilisation for the local government and to help provide skill training for the youth. A handful of UCs already perform some of these functions, but it appears most do not. Those who do perform 
them do so at their own discretion and volition, lacking consistency and, very often, any support from the government or community.

Regarding public services, community residents expect their Unit Committees to help in solving public service provision problems, especially waste collection and disposal, electricity supply, water supply, education and healthcare. Concerning waste collection and disposal, respondents indicated that the UCs could play a key role to ensure that waste collection is always done on time, garbage bins are used in homes, and large waste containers are in good condition at all times. The UCs are also expected to play leading roles in organising clean up exercises through communal labour in the areas they represent. More broadly, the UCs are expected to collect information about waste management problems and other public services, and pass these on to the service providers, and to ensure that they act on them. They are also expected to monitor public services in general to check whether they are working satisfactorily or not, and to report to the responsible organisations. Some respondents went as far as suggesting that UCs should act as sanitary inspectors since they are always on the ground in the communities (interview with community member, Agona East, 8 March 2014). Concerning security, some residents in rural communities indicated that UCs should set up watchdog groups to provide security for the community, especially where there is no police station or very few security personnel serving several communities; UCs should assist the police in dealing with security problems and to protect communities from criminal activity. However, these are expected to be undertaken together with the Assembly members.

Water supply was another major problem in many communities both rural and urban in the areas studied. The problems revealed include lack of pipelines that deliver drinkable water or instances where pipelines exist but the water does not run frequently when needed. Many such communities have had to rely on hand-dug wells or boreholes, some of which produce unwholesome water or no water at all. Some respondents in such communities indicated that UCs should help in solving these water provision problems by reporting these to the appropriate institutions for the problems to be addressed. Electricity supply was also identified as one of the most problematic public services, especially with the frequent power-cuts and load-shedding (interview with community member, 16 May 2014). Respondents indicated that they want UCs to help fix electricity problems by reporting areas that have no electricity supply at all, faults and outages to the power providers. UCs could also help with installation, smooth operation and management of street lights installed in communities. This was noted as a very problematic issue because in urban areas where streetlights have been installed, the lights are left burning throughout the day when they are not needed; however, in the night when they are actually needed for safety and security purposes, they go off leaving major streets and residential areas in darkness. Respondents think UCs could surely help 
with this by ensuring that the lights are operated properly and eliminate this waste of energy and money (interviews with local government official, Agona West, 7 May 2016; community members, Agona West, 10 May 2016). Generally, respondents expect the UCs to report any problems concerning public services delivery to the local government, and to work with committees whose functions relate to the issues concerned.

With reference to education, respondents indicated that UCs should be involved in managing community schools such as helping to check on teachers who do not attend school regularly or are persistently late, and to help improve the academic performance of pupils in the Basic Education Certificate Examinations. The UCs are also expected to ensure children and youth go to school, or to help them acquire employable skill instead of seeking quick cash through fraudulent activities on the internet especially in the Agona West Municipality. They could also help improve regular attendance of pupils to school and to ensure that parents are committed to pupils' education through prompt payment of levies, provision of materials, participation in Parent-Teacher Association activities, and others. Regarding civic education, community residents expect UCs to educate the public on what to do and what to avoid generally as good citizens; and to know their rights and duties or responsibilities as citizens (interview with community member, Gomoa West, 23 June 2014). Activities by UCs in this direction could also include educating community members about common health problems and how to deal with them; providing information services, involvement in education promotion campaigns, and mobilising community members to participate in public activities.

With reference to development projects, many respondents were of the view that UCs should be involved in monitoring and execution of projects where feasible, and that decisions concerning projects need to be taken with the involvement of the community, UCs, Assembly members, the chiefs and elders. This should not be left to the discretion of the local government alone as is currently the case in many communities. Communal labour was noted as very useful in supporting community level infrastructure projects and UCs should be involved in organising residents, in conjunction with chiefs and elders, to support project execution through this. In many rural communities, communal labour is still very effective for maintaining environmental cleanliness and for supporting public projects, and UCs should be involved in organising these. However, in urban areas, communal labour has practically ceased due to involvement of private contractors and political polarization. Regarding revenue mobilisation, some respondents indicated that UCs should be involved in collecting revenue for the Assembly, and in the management of community level finances. This would also create avenues through which UCs could be resourced to undertake their duties or play their expected roles in the communities they represent (interview with UC member, 
Gomoa East, 1 February 2014). Some argued that this would make the UCs feel that the government sees them as an important part of the local governance process.

\section{Relations between UCs and Assembly members}

Local citizens expect better cooperation between Assembly members and UCs, to work together, and to meet regularly to address community needs and concerns. However, this was not the case in many localities. Respondents cited instances where UCs and Assembly members could not meet even once for the entire four year duration of their terms of office, even though they live in the same community (interview with UC member, Gomoa West, 19 June 2014). This was mainly because they support different political parties and could not find any common grounds to work together or to seek the interests of the community they represent. Several respondents indicated dissatisfaction with this situation and indicated that they want the UCs and Assembly members to work together, and to meet regularly. Effective engagement between community residents and UCs was also lacking. Citizens at the community level expect that after every meeting, the UCs should inform the entire community about what was discussed and the decisions that have been taken, so that community members become aware of what is going on (interview with community member, Gomoa West, 21 June 2014). This was often not done and respondents want this to change. UCs are also expected to organise community-based meetings regularly to address issues of concern, and to assist the Assembly members to organise public fora to listen to the people in the community. Together with the Assembly member, they are expected to inform members of the community about problems and developments in the communities and at the local government level. Relations between UCs and the local government were also seen as unsatisfactory. Respondents indicated that they expect the UCs to be involved in bringing their community problems to the attention of the local government or Assembly, and to liaise between the community and the Assembly to address the problems. However, this was not happening. They also expect the UCs to work with their Assembly member and the District Chief Executive to solve public service delivery problems, and serve as the mouthpiece of community to the Assembly, together with the Assembly member.

\section{Actual Activities of UCs}

The study investigated what Unit Committees actually do in the communities they represent, and the responses revealed a remarkable divergent picture regarding activities of UCs operating in older districts and in more urbanised communities; and those operating in newer districts and in less urbanised areas. The two older districts in this study were Gomoa West and Agona West, and the newer districts were Gomoa East and Agona East. It appears Unit Committees in newer, less urbanised districts perform 
better than those in older, more urbanised districts, at least in the views of respondents in this study. For example, in the Gomoa West district, when respondents were asked about the current and general activities of UCs, many of them indicated that they are not involved in any activities in the communities. Many others indicated that UCs are not involved in any activities in the communities partly because they receive no information from the local government or Area Council about what is being done, or what they should be doing. Thus, Assembly members appear to be working with the local government with little or no involvement of the UCs, and this seems to have cut them off from most processes and activities at the local level. One respondent stated the following in relation to this issue: 'the Unit Committees are not working at all but I will put the blame on the Assembly members; they do not tell the UC members what they should do' (interview with community member, Gomoa West, 20 June 2014).

In the Agona West district, a similar situation seems to prevail. Several respondents indicated that the UCs were not functioning or not active (interviews with community elder, 14 June 2014; community members, 9 June 2014; 12 June 2014; 15 June 2014, etc). Others indicated that they were not operational in the communities, were ineffective and doing no work. Other respondents went as far as stating that UCs exist only by name and not by action, not knowing what they should be doing, and should be scrapped. Indeed, in the urban settlements studied, there were no UCs in many units or areas because people refuse to stand for election due to constant insults received from community residents and lack of motivation for the work they do. However, some respondents expressed positive views. In rural settlements, they indicated that UCs see to it that the community is clean by organising communal labour to clean streets, desilt gutters and clear bushes in public areas. In other instances, they served as a link between the community and the local government through the Assembly member.

In the Gomoa East District, respondents indicated that UCs were generally involved in communal labour and cleaning of towns. They also report community problems to the District Assembly though they do not often receive desired responses. They also help to resolve problems regarding pupils in community schools, together with teachers (interview with UC member, 10 January 2014). Other activities include providing security at night, and forming watchdog groups during upsurge of criminal activities (interview with UC member, 1 February 2014). They also help in educating users of public services such as the NHIS and are often involved in organising events in the community. However, some respondents shared a different view, and indicated that most UCs were not active, and were unable to undertake activities in the absence of the Assembly member.

In the Agona East district, many respondents indicated that UCs were involved in several activities such as assisting the Assembly members to identify problems and to help solve 
them. They also provided security at night when the need arises, and were involved in organising and supervising communal labour in communities such as street sweeping on specified days. They also ensure that children under 18 years of age do not go out at night but stay home to study in some localities. Regarding public services, UCs sometimes report problems concerning electricity supply to the Electricity Company of Ghana for redress (interview with community member, Agona East, 28 March 2014). They also help to extend electricity by fixing poles for grid lines to communities (interviews with UC member, 14 March 2014; community member, 12 March 2014). Concerning water, when problems arise in connection with water supply, they sometimes report to the Ghana Water Company for action to be taken. Other activities mentioned include collecting community levies and receiving visitors to the community (interview with community member, 13 March 2014). In some communities, they also make sure children do not labour for their parents on the farms, businesses or markets during school hours (interview with UC member, Agona East, 3 April 2014).

\section{Problems Affecting UCs in the Performance of Functions}

The study also sought the views of respondents regarding problems that UCs face in their activities, and several of these were raised. Respondents indicated that UCs face many problems, the major ones being lack of training about their roles and responsibilities, and lack of resources to execute these. There is also a feeling among citizens that the government does not recognize the UCs as an important structure of the local government system, and this needs to be rectified. Some suggested that this could be addressed by giving them adequate training and resources to undertake their activities, similar to what is being done for the Assembly members who now receive motorbikes and other financial support for their work. Currently, the UCs have no funding from the local government or from the communities they represent, and are left with no resources to perform their roles and responsibilities, or to meet the expectations of community residents. In other instances, UCs face disrespect from the community members, insults from the public, and general disregard for their role (interview with UC member, Gomoa East, 9 January 2014; interview with local government official, Agona East, 3 March 2014)). Some community residents simply refuse to heed calls for participation in communal labour or accept their authority to organise such activities (interview with community member, Agona East, 28 March 2014). In some communities, drug-users, popularly known as wee boys often threaten UC members with cutlasses, physically assault some, and abuse them verbally with little repercussions from the community leaders or the state (interview with community elder, Agona West, 13 June 2014). Respondents also indicated instances where parents, especially mothers, fight the UCs when they ask pupils to stay home after 8pm to study, and not to be on the streets. Another major problem affecting the UCs is lack of cordial relations between the UC 
members, mainly because the community itself is divided along political lines and the same situation prevails among the UC members (interview with community member, Gomoa East, 21 January 2014). Under such conditions, UCs become extremely attached to political parties, highly politicised, partisan and dysfunctional to the extent that they cannot agree to do anything together for the community they represent. If it happens that the Assembly member and the UCs belong to different political parties, then the dysfunction is extended to relations between the UCs and the Assembly member, often involving the traditional rulers as well.

To sum up, the study revealed lack of support from the state or District Assembly for the UCs to undertake their activities, and they appear left to their own devices. Thus, many capable people do not feel motivated to serve as UCs, which explains why there are no UCs in some communities or units (interview with Assembly member, Gomoa East, 23 January 2014). This is because no one stands to be elected for the role during local government elections. In some communities too, the chiefs and elders take over the work of the UCs, leading to power struggles over authority to undertake activities due to blurred boundaries over roles which are not clearly defined (interview with Assembly member, Agona East, 6 March 2014).

\section{Statutory versus Local Expectations from UCs}

This study set out to address three main questions. First, what are the issues that matter to local citizens, and what do they expect their locally elected representatives to do about them? Second, how do these interface with national statutory expectations or functions assigned to local representatives? Third, what do the findings reveal about policy making and practice in local governance. The first question has been addressed in the sections above, and we now turn our attention to the remaining questions.

The UCs are closest to the people at the local level and are located at the very bottom of the local government structure. Their functions, as stated in Legislative Instrument 1967, Fourth Schedule, Regulation 25 (2010), include the following:

1. Supervise the staff of the District Assembly assigned duties in its area of authority;

2. Assist the Town Council to enumerate and keep records of all rateable persons and properties;

3. Assist any person assigned by the Urban or Town Council to collect allocated and contracted revenues on behalf of the Urban or Town Council;

4. Mobilise members of the Unit for the implementation of self-help and development projects; 
5. Monitor implementation of self-help and development projects;

6. Take all lawful steps to abate any nuisance;

7. Be responsible, under the guidance of the Registrar of Births and Deaths, for the registration of births and deaths in the Unit;

8. Provide a focal point for the discussion of local problems and take remedial action where necessary or make recommendations to the Assembly where appropriate through the relevant Urban, Zonal or Town Council;

9. Organise communal and voluntary work especially with respect to sanitation;

10. Make special proposals to the Assembly for the levying and collection of rates for projects and programmes through the relevant Urban, Zonal or Town Council;

11. Educate the people on their rights, privileges, obligations and responsibilities in consultation with the District branch of the National Commission for Civic Education;

12. Monitor the implementation of any enactment regulating the use of chain saws in the Unit;

13. Oversee the performance of staff of the Urban, Zonal or Town Council and District Assembly assigned to work in the Unit;

14. Perform other functions as may be delegated by the Urban, Zonal or Town Council or the District Assembly.

A close examination of the roles assigned to UCs in LI 1967, in juxtaposition to what community residents expect from the UCs reveals sharp differences or asymmetric expectations. The first three functions relate to supervision of staff of the District Assembly, assisting in enumeration and maintenance of records on rateable persons, and assisting in the collection of allocated and contracted revenues; these appear well outside the expertise of the UCs. Many of the UCs studied were not even aware of these functions and have not been given any capacity to undertake these functions. It did not also feature in the expectations that community residents have regarding the functions of the UCs. Clearly, there exist a disjuncture between what the statutes expect and what citizens expect of the locally elected representatives regarding the functions.

With reference to four and five, that is, mobilise members of the Unit for the implementation and monitoring of self-help and development projects, there appears to be some confluence here because local citizens indicated that they expect UCs to help in revolving problems with education and healthcare, which are of developmental importance. A similar argument could be made about communal labour (nine) with respect to sanitation. However, this is mostly applicable in rural communities and almost non-existent in urban communities due to involvement of private contractors and political polarisation. Functions six, seven and eight were also found to be 
problematic. Most UCs interviewed were not even aware that taking steps to abate any nuisance was part of their functions. There was some awareness about their role in the registration of births and deaths, but UCs were practically doing nothing in connection with this. In some rural communities, UCs provide some space for discussion of local matters and brought these to the attention of the relevant bodies, especially concerning water and electricity supply; apart from these, not much has been happening, and the situation appears much worse in urban communities. Function 11 in Fourth Schedule of LI 1967 also somewhat falls in line with what citizens expect of the UCs and this came up in the study that they could help in educating citizens about their rights, privileges, obligations and responsibilities. Thus, there is another convergence here. However, the remaining functions in number 10,12,13 and 14 did not feature in what local citizens expect of their UCs and neither did the UCs interviewed show awareness of these functions.

Community residents basically expect their UCs to help address their everyday problems, and public services delivery comes as a priority. This was followed by communal and voluntary work with respect to sanitation, to help maintain a clean environment. These appear to be the strongest locus of convergence between statutory expectations and local expectations. The next area of convergence concerns educating people on their rights, privileges and responsibilities as citizens. Understandably, actual activities of UCs have focused on communal labour and trying to help resolve public service delivery problems; these succeed mostly in rural communities, and rarely, in urban settings. Apart from these, most of the statutory roles assigned to UCs under LI 1967 did not even feature in what citizens at the local level expect the UCs members to be doing. Indeed, the UCs themselves were not even aware of the roles that have been assigned to them in LI 1967, and appeared left to their own devices. As groups, most of the UCs were riddled with conflicts among the members, with the Assembly members, and with the traditional authorities. They also had to contend with insults and physical assaults from community members who have little value for their role. Thus, there appear to be significant disjuncture between local expectations, statutory expectations, and what the locally elected representatives have actually been doing in the communities they represent. What accounts for this situation? It appears statutory roles were assigned to the locally elected representatives with little consideration for local realities, problems, expectations and needs. This has led to a situation where roles assigned by the state run asymmetrically to what local citizens expect their elected representatives to be doing: addressing the issues that matter to them most. 


\section{Conclusion and Reflections on Policy and Theory}

The analysis of local expectations, statutory functions, activities and situation of the Unit Committees, the locally elected representatives, shows several points of dissonance or asymmetry in expectations, a consequence of top-down policy making in local governance. Ordinarily, the assignment of roles should be based on an assessment of the problems or aspirations that are to be addressed. This process allows consideration of pertinent local issues and helps to counter the perennial problem of lack of information on local realities, especially in local governance and in community development in general. The lack of consideration of local concerns obviously led to the exclusion of common community problems and public services delivery which local citizens want their elected representatives to address. Besides, some of the statutory roles are simply too lofty for the local representatives to assume. For example, the average Unit Committee members encountered in communities are not in any position to supervise staff of the local government assigned to their units to undertake some responsibility. Second, they simply do not have the capacity or clout to oversee the performance of urban, zonal, town council staff working in their areas of jurisdiction, as stipulated in LI 1967. They clearly cannot fulfil these roles in their present state.

Furthermore, the statutory roles have been assigned without any training, funding or a mechanism to provide these. As it is often said, 'you put your money where your mouth is.' That is, if you say that something is very important to you, you demonstrate this through the financial commitment you make to it. Thus, if government considers UCs to be an important structure in the local government set-up, why has no funding stream been assigned to it? This situation lends support to the assertion by many that the state does not value the role of UCs as the base structure of the local government system in Ghana. However, the UCs are the ones who are in constant direct touch with citizens, and much closer than the bureaucrats in the local administrations. There were other important issues that were glossed over in the legislation regarding functions of UCs, which somewhat accounts for the existence of blurred boundaries with the traditional rulers. This has led to the emergence of local power struggles involving chiefs, Assembly members and UCs. Political polarization has made this worse. Some UCs play important roles in rural communities such as organising communal labour, education, healthcare, organising community level events, and others. Some are already involved in public services provision and revenue mobilisation. Policy making on local governance therefore needs to create spaces that allow pressing local issues to be addressed, especially with respect to public services delivery. At present, this is lacking. These have led to dissonance between national statutory expectations and citizen expectations in local governance regarding what locally elected representatives should be doing. 
Theoretically, decentralisation is expected to make government better able to deliver programmes and services that address local needs and to build the capacity of local actors to play leading roles in the development and management of their areas and communities (Work, 2002:3-4; UNDP, 2002:7-14). However, this does not appear to be happening because some structures and functions have been statutorily created but are operationally dysfunctional. It is also expected that with government brought closer to citizens, decentralisation would provide informational advantage to enable local authorities provide services that respond to local needs, and attain efficiency in service delivery (Brinkerhoff \& Azfar 2006:21; Smoke, 2003:9). It is poignant to note in this study that local realities appear to have been ignored in crafting legislation regarding local institutions or decentralised structures. The top-down approach to policy making continues to hold sway, leading to significant disjuncture between local realities and nationally assigned functions for locally elected representatives. Finally, citizens' demand for public services continues to remain as a rallying point to engage public authorities (Narayan, 2002; World Bank, 2004). The study found that this is still very important; thus, functions of locally elected representatives could be recast to focus more on public services delivery, and to work towards greater devolution in decentralised governance.

\section{References}

Ayee, J.R.A. (2000). Decentralization and Good Governance in Ghana, unpublished paper of May 2000 prepared for the Canadian High Commission, Accra, Ghana.

Ayee, J. R. A. (2005). Accountability for Pro-poor Local Governance in Africa, Paper for Local Governance and Poverty Alleviation Workshop, Joint African Institute and African Development Bank, Tunis, June 21-24.

Azfar, 0, Kahkonen, S. and Meagher, P. (2001). Conditions for Effective Decentralized Governance: A Synthesis of Research Findings, College Park, University of Maryland, IRIS Center, Working Paper No. 256, March 2001.

Bardhan, P. (2002). Decentralization of Governance and Development, Journal of Economic Perspectives, Volume 16, Number 4, Fall 2002, pp.185-205.

Binswanger, H. P. and Aiyar, S. (2003). Scaling Up Community-Driven Development, Theoretical and Underpinnings and Program Design Implications, Policy Research Working Paper 3039, The World Bank, Washington DC.

Botchwey, G. (2011). Intersections in Community Development and Decentralisation: Experiences from Ghana. The University of Leeds (PhD Thesis).

Botchwey, G. (2014). Granting Voice without Power? An Interrogation of Ghana's Decentralisation Conundrum. The Social Educator, Vol. 4, Issue 2, pp.64-84. 
Brinkerhoff, D. W. and Azfar, 0 (2006). Decentralization and Community Empowerment: Does community empowerment deepen democracy and improve service delivery? Paper prepared for USAID, Office of Democracy and Governance, October 2006, Washington DC.

Crawford, G. (2004). Democratic Decentralisation in Ghana: Issues and Prospects, POLIS Working Paper No. 9, February 2004, University of Leeds.

Crawford, G. (2009). Making democracy a reality'? The politics of decentralisation and the limits to local democracy in Ghana. Journal of Contemporary African Studies, 27: 1 , pp. $57-83$.

Institute of Local Government Studies (ILGS) (2008). Introduction to Ghana's Local Government System, Accra, ILGS.

Jetté, C. (2005). Democratic decentralization and poverty reduction: The Bolivian case, UNDP Oslo Governance Centre.

Larbi, O. W., Antwi, A, and Olomolaiye, P. (2003). Compulsory Land Acquisition in Ghana: policy and praxis, Land Use Policy, 21 (2004), pp.115-127.

Manor, J. (1995). Democratic Decentralisation in Africa and Asia, IDS Bulletin, Vol 26, No 2, pp.81-88.

Manor, J. (2006). Extending Services over the Last Mile: Bridging the Gap between Intermediate and Local, Paper presented at the Politics of Service Delivery in Democracies: Better Access for the Poor, Expert Group on Development Issues, Lidingö, Sweden, April 27-28.

Ministry for Local Government and Rural Development (2010). Local Government: Urban, Zonal and Town Councils and Unit Committees Establishment, Legislative Instrument 1967, Assembly Press, Accra.

Ministry of Justice (2005edn). The 1992 Constitution of the Republic of Ghana, Accra, Allshore Co.

Narayan, D. (2002) Empowerment and Poverty Reduction: A Source Book, PREM, The World Bank, Washington DC.

Nkrumah, S. A. (2000). Decentralisation for good governance and development: The Ghanaian

Experience, Regional Development Dialogue, Vol 21, No1, pp.53-67.

Olowu, D. and Wunsch J S (2004) Local governance in Africa: The challenges of democratic decentralisation, London, Lynne Rienner.

Parliament of the Republic of Ghana, (1993). Local Government Act, No. 462, Accra. 
Ribot, J. C. (2002). African Decentralization: Local Actors, Powers and Accountability, UNRISD Programme on Democracy, Governance and Human Rights, Paper Number 8, December 2002.

Rondinelli, D. and Cheema, G. S. (eds), (1983). Implementing decentralization policies: an introduction. In Decentralization and Development: Policy Implementation in Developing Countries. Beverly Hills, Sage, pp.9-34.

Smoke, P. (2003). Decentralisation in Africa: Goals, dimensions, myths and challenges, Public Administration and Development, Vol 23, No. 1, pp.7-16.

Steiner, S. (2007). Decentralisation and Poverty: Conceptual Framework and Application to Uganda, Public Administration and Development, No 31, November 2006, GIGA Working Papers.

UNDP (2002). Local governance for poverty reduction in Africa: AGF-V Concept paper, Africa Governance Forum.

\section{United States Agency for International Development (USAID) (2003).} Decentralization in Ghana: An Assessment' (mimeo).

Wardell, D. A. and Lund, C. (2006). Governing Access to Forests in Northern Ghana: Micro-Politics and the Rents of Non-Enforcement, World Development, Vol. 34, No. 11, pp.1887-1906.

World Bank (1999). World Development Report 1999/2000: Entering the 21st Century, Washington DC.

World Bank (2002). Issues: Paper for a World Bank Social Development Strategy, Draft, Social Development Department, Washington DC.

World Bank (2004). World Development Report 2004: Making Services Work for the Poor, Washington DC.

Work, R. (2002). Overview of Decentralisation Worldwide: A Stepping Stone to Improved Governance and Human Development, Paper for 2nd Conference on Decentralisation Federalism: The Future of Decentralizing States? 25-27 July, 2002, Manila, Philipines, UNDP. 